\title{
ポリビニルアルコール水溶液の超音波音速ならびに吸収*
}

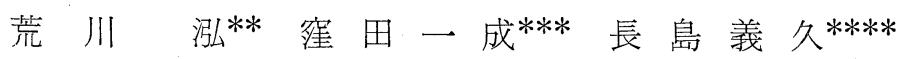

\section{Ultrasonic Velocity and Absorption of Aqueous Solutions \\ of Polyvinyl Alcohol}

by

Kiyoshi Arakawa,

(Research Institute of Applied Electricity, Hokkaido University, Sapporo)

Kazushige Kubota and Yoshihisa Nagashima

(Fuji Electric Manufacturing Co., Ltd., Kanagawa) (Dainihon Toryo Co., Ltd., Kanagawa)

An ultrasonic pulse technique was applied to the rheological study of aqueous solutions of polyvinyl alcohol in the ultrasonic frequency region.

Two samples of polyvinyl alcohol were used. The average degree of polymerization of sample A and sample B was 1800 and about 2000 , respectively. The content of residual acetyl groups was smaller than $0.7 \%$ by mole for sample $A$ and was $12.2 \%$ by mole for sample $B$. The molecular weight distribution curve of sample A was obtained by the successive precipitation method proposed by Spencer.

Ultrasonic velocity and absorption were measured over the temperature range of $3 \sim 70^{\circ} \mathrm{C}$ for the solutions in the concentration range of $5 \sim 15 \%$ by weight. The frequency of ultrasound was $1 \cdot 42 \mathrm{Mc} / \mathrm{s}$ throughout the experiment.

The following results were obtained:

In sample $\mathrm{A}$, the temperature dependence of ultrasonic velocity has similar characteristics on the whole to that observed in pure water, and the ultrasonic velocity increases with the increase of concentration. In sample B which contains acetyl groups by $12 \cdot 2 \%$ by mole, however, the behavior is fairly different. In the low temperature region no remarkable difference between $\mathrm{A}$ and $\mathrm{B}$ is found, but above $40^{\circ} \mathrm{C}$ it is clearly seen that sound velocity is smaller than that for the solutions of sample A which have the same concentration. The tendency of smaller sound velocity becomes more evident in high temperature region, and the velocity decreases with increase of polymer concentration in sharp contrast to the case of sample A. The velocity-temperature curve of solutions of sample B has a broader peak than in pure water, and the peak becomes lower, and the peak temperature shifts to lower temperature side. For example, in the case of the $10 \mathrm{wt} . \%$ solution of sample $\mathrm{B}$ the peak temperature is about $50^{\circ} \mathrm{C}$, whereas the value for pure water is $74^{\circ} \mathrm{C}$.

The average absorption coefficient in the temperature range of the present experiment increases with increase of concentration in both samples. The data for solutions of sample B are seen to be larger than those for solutions of sample A of the same concentration.

The longitudinal elastic modulus $M_{1}$ and the longitudinal loss modulus divided by angular frequency $M_{2} / \omega$ are obtained from the data of sound velocity and absorption.

(Received Jan. 18, 1963)

* 原稿受付 昭和38年 1 月 18 日

** 北海道大学応用電気研究所

**** 富士電機製造株式会社

*****大日本塗料株式会社
1. は じめに

PVA 水溶液のレオロジ一的性質については, 定常 流粘性, 低周波動的性質, 可聴周波動的性質等の面で 
はかなり研究がなされているが，超音波領域での動的 性質に関しては超音干渉計による研究以外は少ない. 超音波領域において音速ならびに吸収を同時に測定す るには近年発達してきたパルス法の技術が最も好都合 である．著者らは高分子溶液の超音波領域での動的性 質を調べるためにパルス法による超音波音速ならびに

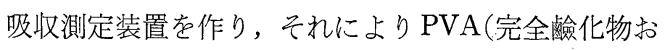
よび部分鹼化物) 水溶液の音速ならびに吸収を測定し た。その結果について報告する。

\section{2. 実験装置ならびに測定法}

パルス法は Pinkerton らにより始められたが，本研 究において製作した装置は原理的にはそれらと同じも のである。装置のブロックダイヤグラムを Fig. 1 に 示す.

繰返周波数 2〜 $5 \mathrm{kc} / \mathrm{s}$. パルス幅 $5 \sim 10 \mu \mathrm{s}$ のパルス をパルス発生器で作り, 高周波発振器でパルス高周波 にしこれを試料セルの送信水晶でパルス超音波にし て, 試料溶液をとおす。それを受信水晶で受けてパル ス高周波にした後, 増幅器を経てシンクロスコープの 垂直軸に入れる。一方発振器から試料セルをとおさず に抵抗減衰器を経て同じく増幅器にはいりシンクロス コープにはいるようになっている。

音速を測るにはマイクロメーターで水晶間距離を変 えるとブラウン管上で試料をとおしたパルスの位置が 移動する，それでブラウン管上の指示線を通過する高 周波の数と水晶の移動距離との関係から音速を求める. 吸収係数は，試料中をとおしたパルスと試料をとおさ ず減衰器をとおしたパルスとの比較で求める。すなわ ち, 水晶間距離を変化させて, 減衰器をとおしたパル スと試料中で減衰させられたパルスとが等しい高さに なるようにした場合の減衰器の読みを水晶間距離に対 してプロットして, その傾きから減衰(吸収)係数 $\alpha$ を 求める. 水晶間距離は常に Fresnel Region の範囲内

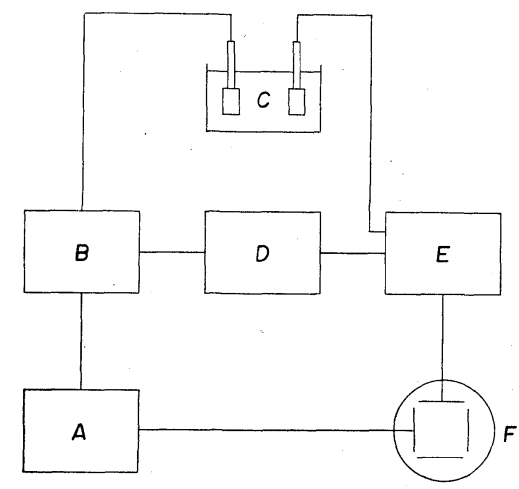

Fig. 1 Block diagram of the apparatus
A: Pulse generator
B : Oscillator
C: Cell
D : Attenuator
E: Amplifier
F : Synchroscope

にあるように設計されている。

送信水晶からの距離 $x$ のところでの振動による变位 をほとすれば，

$$
\xi=\xi_{0} e^{i \omega(t-x / c *)}=\xi_{0} e^{-\alpha x} e^{i \omega(t-x / c)}
$$

でただし， $c^{*}$ は複素音速， $c$ は音速， $\omega$ は角周波数， $t$ は時間である。

広い媒質中の縦波に対する複素弾性率 $M^{*}$ は

$$
M^{*}=M_{1}+i M_{2}=K^{*}+4 / 3 G^{*}
$$

$K^{*}$ は複素体積弾性率， $G^{*}$ は複素剛性率である.

その実数部分 $M_{1}$ および虚数部分 $M_{2}$ はおのおの

$$
\begin{aligned}
& M_{1}=K_{1}+4 / 3 G_{1}=\rho C_{l}^{2} \frac{1-\left(\frac{\alpha_{l} C_{l}}{\omega}\right)^{2}}{\left\{1+\left(\frac{\alpha_{l} C_{l}}{\omega}\right)^{2}\right\}^{2}} \\
& M_{2}=K_{2}+4 / 3 G_{2}=\rho C_{l}^{2} \frac{2\left(\frac{\alpha_{l} C_{l}}{\omega}\right)}{\left\{1+\left(\frac{\alpha_{l} C_{l}}{\omega}\right)^{2}\right\}^{2}}
\end{aligned}
$$

で与えられ，音速 $C_{l}$, 吸収係数 $\alpha_{l}$ の測定から $M_{1}, M_{2}$ が求められる。 suffix $l$ は縦波に対するものであるこ とを示している。 $\rho$ は密度である。

\section{3. 試料市よび測定}

試料 PVA は次の 2 種類を用いた。

試料 $\mathrm{A}$ : 平均重合度 1800 , 残存酢酸基 0.7 mole $\%$ 以下

試料 B : 平均重合度約 2000 , 残存酰酸基 $12 \cdot 2$ mole $\%$

試料Aの分子量分布は Fig. 2 に示されている. 分配 曲線は Spencer 法で求めた。

湘定に際しては, 試料Aについては 5, 7·5, 10, 15 wt. \%, 試料Bについては 5 および $10 \mathrm{wt} . \%$ の水溶液 を作り，3〜 $70^{\circ} \mathrm{C}$ の温度範囲にわたって $10^{\circ} \mathrm{C}$ 間隔で 各温度について音速ならびに吸収を測定した。周波数 は全部 $1.42 \mathrm{Mc} / \mathrm{s}$ である. Fig. 3 および 4 に試料 $\mathrm{A}$ および Bの水溶液の音速, Fig. 5 および 6 に試料 Aお よび $\mathrm{B} の$ 水溶液の吸収についての測定結果が示されて

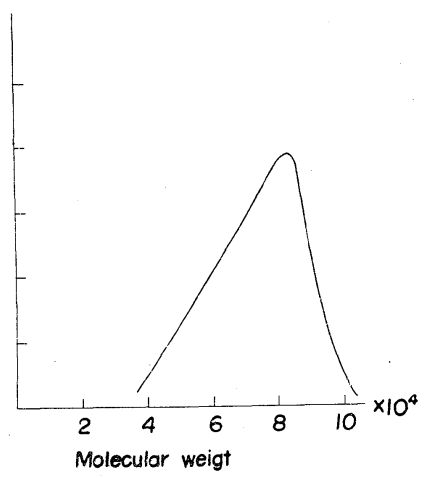

Fig. 2 Molecular weight distribution function of sample $A$ 


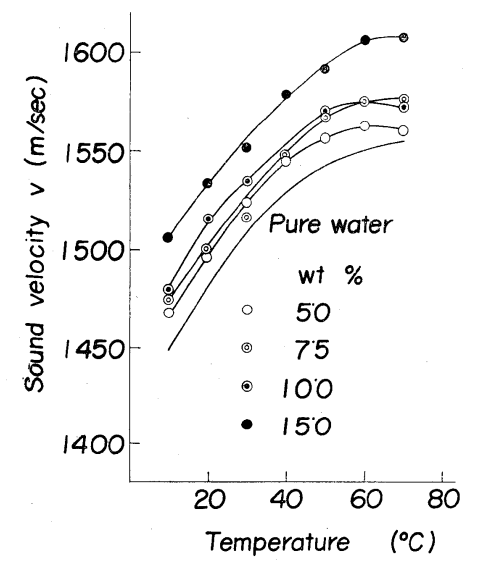

Fig. 3 Sound veloctity of the aqueous solution of Sample A

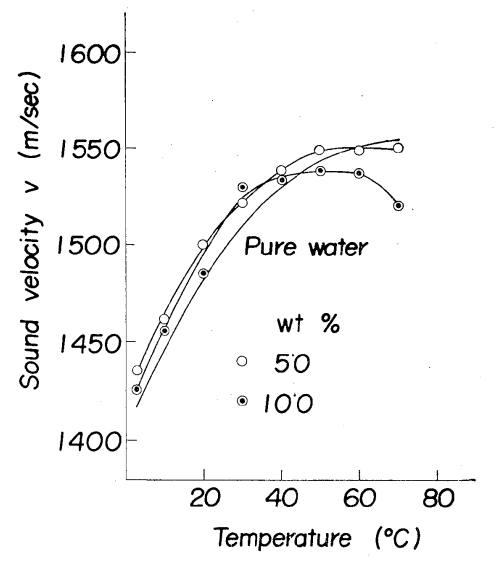

Fig. 4 Sound velocity of the aqueous solution of sample B

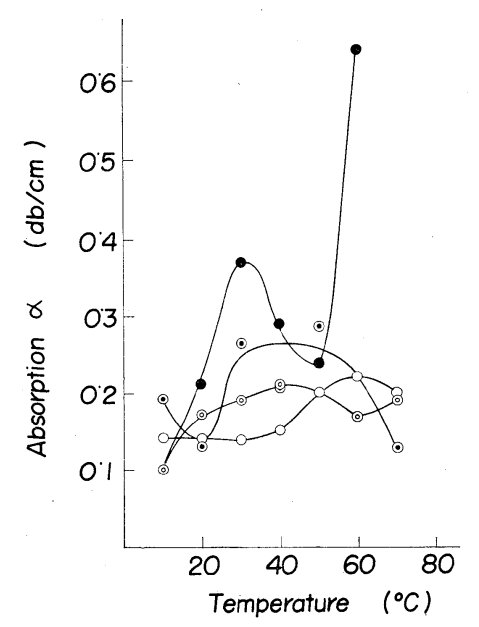

Fig. 5 Sound absorption of the aqueous solution of sample A
いる.なお Fig. 3 および 4 には比較のために純水の 音速の值が記入されている.

\section{4. 結果}

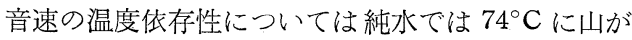
あることはよく知られている。試料 $\mathrm{A}$ の場合には音速 が最大值を示す温度は純水の場合より若干低くなるよ うな傾向もみられるが，まずあまり差はないといえよ う. 同一温度で比較すれば，全体として濃度の増大と ともに音速は増大しているが, 温度変化の傾向はあま り変わらない，要するに，濃度增大とともに全体とし て值は増大するが，温度依存性の傾向としては純水の 場合とあまり変わらないということができる.

酢酸残基をほとんど含まない試料 $\mathrm{A}$ の場合に比べて, それを $12 \cdot 2$ mole \% 含む試料 B の水溶液の音速は Fig. 4 を Fig. 3 と比較すれば明らかであるようにかなり 異なった特徴を持っている( A と B で平均重合度は Bのほうが高いがだいたい同じ程度である). Fig. 4 において低温の部分では Fig. 3 の場合におけるよう な濃度とともに増大する傾向がみられないことを除い ては，温度变化の傾向には大きな变化はみられない。 しかし高温 $\left(40^{\circ} \mathrm{C}\right.$ 以上) になると事情が变わってきて,

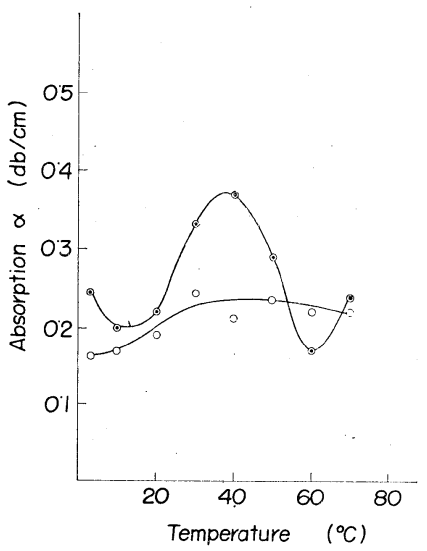

Fig. 6 Sound absorption of the aqueous solution of sample B

Table 1

\begin{tabular}{c|c|c|c|c}
\hline \multirow{2}{*}{ Sample } & Conc. $C$ & $\alpha_{m}$ & $\left(M_{2} / \omega\right)_{m}$ & $T_{\max }$ \\
\cline { 2 - 5 } & (wt. \%) & $(\mathrm{db} / \mathrm{cm})$ & $($ poise $)$ & $\left({ }^{\circ} \mathrm{C}\right)$ \\
\hline \multirow{3}{*}{ A } & 5.0 & 0.17 & 1.8 & 60 \\
& 7.5 & 0.18 & 1.9 & 50 \\
& 10.0 & 0.21 & 2.3 & 50 \\
& 15.0 & 0.24 & 2.8 & 35 \\
\hline \multirow{2}{*}{ B } & 5.0 & 0.21 & 2.1 & 50 \\
& 10.0 & 0.26 & 2.6 & 40 \\
\hline
\end{tabular}




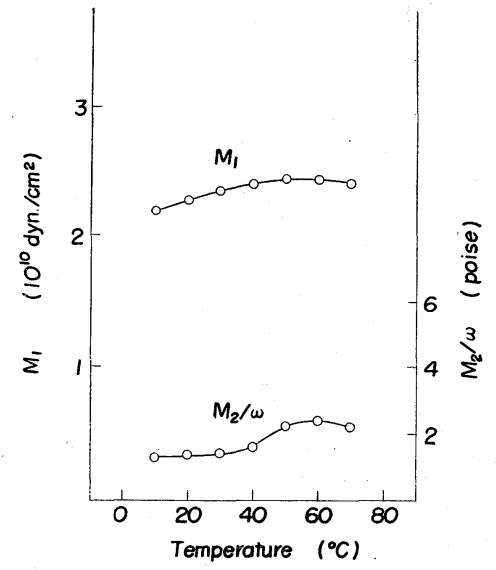

Fig. $7 \quad M_{1}$ and $M_{2} / \omega$ versus $T$ curves of the aqueous solution of sample A (5wt. \%)

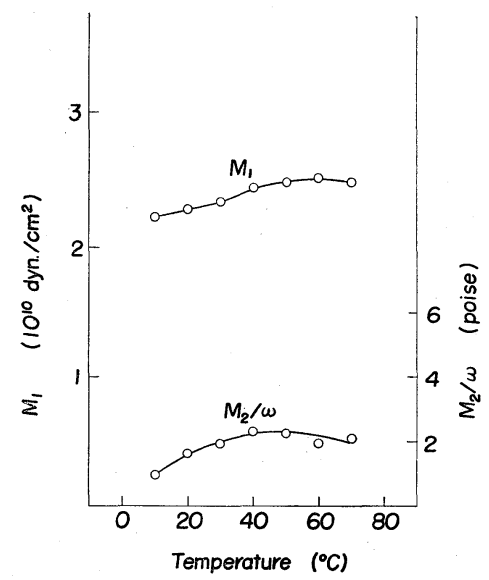

Fig. $8 \quad M_{1}$ and $M_{2} / \omega$ versus $T$ curves of the aqueous solution of sample $\mathrm{A}$ $(7 \cdot 5$ wt. $\%)$

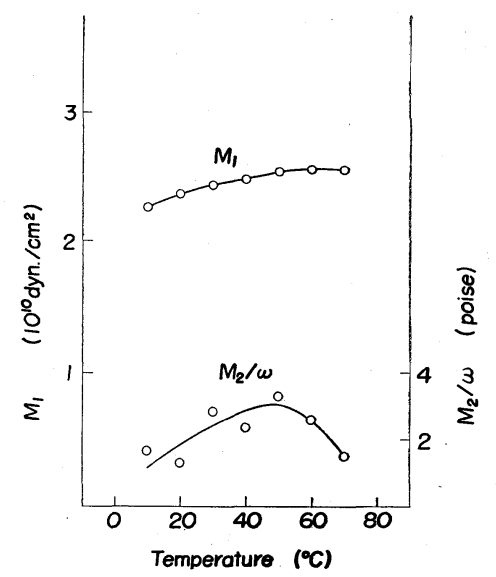

Fig. $9 \quad M_{1}$ and $M_{2} / \omega$ versus $T$ curves of the aqueous solution of sample A (10wt. \%)

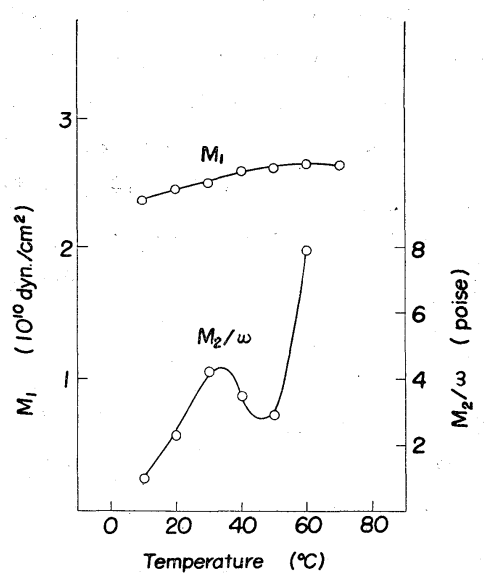

Fig. $10 \quad M_{1}$ and $M_{2} / \omega$ versus $T$ curves of the aqueous solution of sample A (15wt. \%)

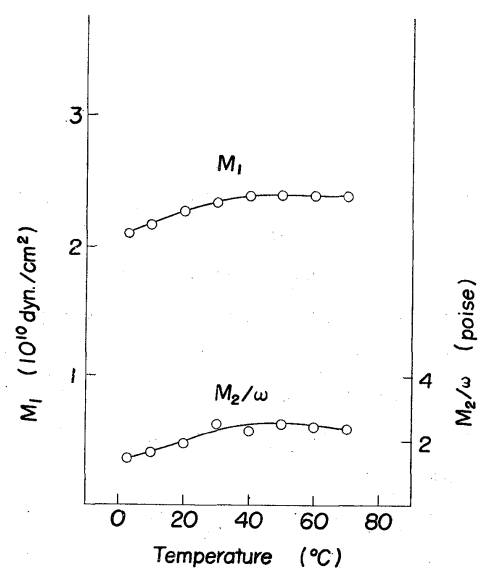

Fig. $11 M_{1}$ and $M_{2} / \omega$ versus $T$ curves of the aqueous solution of sample $B$ (5wt. \%)

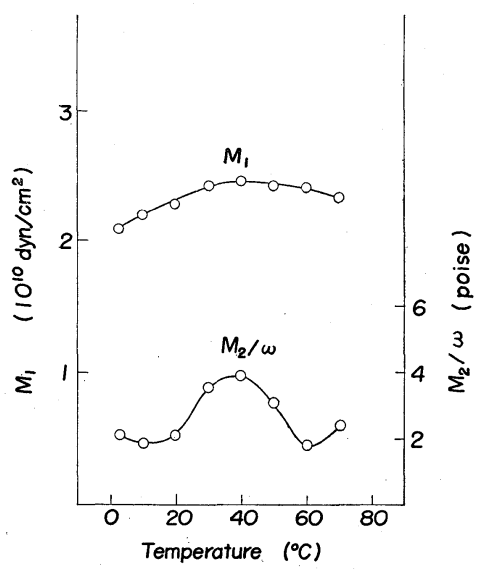

Fig. $12 M_{1}$ and $M_{2} / \omega$ versus $T$ curves of the aqueous solution of sample $B$ (10wt.\%) 
試料 $\mathrm{A}$ の同一濃度の場合に比べてより低くなる傾向が 強く現われてくる. $10 \mathrm{wt} . \%$ の場合は $5 \mathrm{wt} \%$ の場合 より逆に低い值を示すようになり， $50^{\circ} \mathrm{C}$ 以上では純 水の場合よりも低くなる. $5 \mathrm{wt} . \%$ の場合でも $60^{\circ} \mathrm{C}$ 以 上で純水上り低くなる．温度変化の傾向が試料 $\mathrm{A}$ の場 合に比べて全体として幅の広い山になり，その極大を 示す温度が全体としてはっきり低温側に移行する。10 wt. \%の場合，極大を示す温度は約 $50^{\circ} \mathrm{C}$ である。

吸収については Fig. 5 および $6 に$ 示した值の実験 温度範囲における平均值 $\alpha_{m}$-Table 1 に与えられて いる一の值からみられるように濃度とともに上㫒する 傾向がみられ, 全体として試料 Bの場合は試料 $\mathrm{A}$ の同 じ濃度の場合より大きな值を示す。試料 A の $15 \%$ の 場合, $60^{\circ} \mathrm{C}$ 以上で急激な上昇 (Fig. 5) が起こるのは 不可逆的なゲル化過程の初期過程の進行によるものと
みられる（外見的にはこの温度で急激な变化はなかっ た).

(3)式から $M_{1}$ を求め, (4)式から求めた $M_{2}$ を $\omega$ で除いた $M_{2} / \omega$ とともに Fig. 7〜12におのおの各試 料, 濃度に対して与えられている。

Table 1 に上述の $\alpha_{m}$ の他に, $M_{2} / \omega$ の実験温度範 囲での平均值 $\left(M_{2} / \omega\right)_{m}, M_{2} / \omega$ 対温度曲線において $M_{2} / \omega$ の值が極大を示す温度 $T_{\max }$ が与えられている.

\section{参考文 献}

1) T. Soeya and R. Kono, J. Phys. Soc. Japan, 12, 950 (1957), 椎尾, 化学の領域, 11, 440 (1957)

2) J.M.M. Pinkerton, Proc. Phys. Soc. (London) B62, 286 (1949)

和田，高分子実験学講座(高分子学会編)，3，p. 110

3) 松本, 高分子化学, 9, 137 (1952)

4) M. Greenspan and C.E. Tschiegg, J. Res. Nat. Bur. Standard, 59, 249 (1957)

(325 頁より)

68. The Viscoelastic Behavior of Isotactic Polypropylene Fibers, Roy C. Laible and Henry M. Morgan, 269-277

69. Stress-Strain Testing of Rubbers at High Rates of Elongation, Mark L. Dannis, 283-296

70. A Modified Method of Reduced Variables for Stress Relaxation, Franklin S.C. Chang, 297-302

71. Apparatus for Studying the Effects of Rapid Thermal Cycles and High Strain Rates on the Elevated Temperature Behavior of Materials, Warren F. Savage, 303-315

72. Viscoelastic Characterization of Solid Propellants by Transient Test Techniques, J.W. Jones, 328-331

73. The Dynamic Properties of Carbon Black Loaded Natural Rubber Vulcanizates Part II., A.R. Payne, 368-372

74. Relaxation Processes in Vulcanized Rubber, I. Relation among Stress Relaxation, Creep, Recovery and Hysteresis, A.N. Gent, 433-441

75. Relaxation Processes in Vulcanized Rubber, II. Secondary Relaxation Due to Network Breakdown, A.N. Gent, 442-448

76. Stress Relaxation in Molten Polymers (LTE), C. Mussa aud V. Tablino, S21

77. A Theory of Inclusions in Viscoelastic Materials, J.R.M. Radok and Clement L. Tai, 518-528

78. Adhesion Between Viscoelastic and Hard Materials, N.A. Brunt, 548-557

79. Stress Crazing of Some Amorphous Thermoplastics, O.K. Spurr, Jr. and W.D. Niegisch, 585 $-599$

80. Rheological Properties of Viscose, T.E. Hopkines and J.W. Whatley, 600-604

81. Reply to "Digital Recording and Automatic Computation of Film Tensile Stress-Strain Data" (LTE), Martin Segal, S27

82. Dependence of Activation Energy for Viscous Flow of Polyhydrocarbons on Bulk of Substituents (LTE), Hans Schott, S 29

83. Mechanism of the Dielectric and Mechanical B-Dispersion in the Thermosetting Phenolic Resins (LTE), Yuzo Takahashi, S34

84. Dynamic Rheology of Modified Starches, Raymond R. Myers, Carl J. Knauss and Ray D. Hoffman, 659-666

85. On the Discontinuity in the Flow Curve of Polyethylene (LTE), R. Sabia and M.E. Mullier, S42 